УДК 94(470)+94(571.150)

ББК 63.3(2)64-27+63.3(2Рос-4Алт)-27

\title{
Информационное поле политики переселения соотечественников в постсоветской России (на материалах информационных ресурсов Алтайского края)*
}

\author{
В.В. Безгачева
}

Национальный исследовательский Томский государственный университет

(Томск, Россия)

\section{Information Field of the Policy of Resettlement of Compatriots in Post-Soviet Russia (on the Materials of Information Resources of the Altai Territory)}

\author{
V.V. Bezgacheva
}

National Research Tomsk State University (Tomsk, Russia)

Исследовательский подход основан на рассмотрении современной переселенческой политики как стимулирующего этапа непрерывного процесса 1990-2000-х гг. В 1990-е гг., в условиях концептуального рассмотрения переселения соотечественников в рамках вынужденной миграции, в качестве механизма формирования положительного образа использовалось представление переселенцев в качестве жертв военных действий или дискриминации в стране исхода. Концепция же «содействия добровольному переселению соотечественников» требует иного подхода при создании информационного поля. Данная статья посвящена определению соответствия информационного поля политики переселения соотечественников задаче формирования благоприятного отношения к переселенцам и политике содействия добровольному переселению в целом (на примере Алтайского края). Делается вывод о том, что недостаточное использование культурно-исторического дискурса сближает соотечественников как объекта государственной политики с трудовыми мигрантами. Учитывая тот факт, что информация об условиях участия в программе, в том числе в отношении льгот для переселенцев, не носит конкретного характера, а также принимая во внимание комментарии пользователей к рассматриваемым публикациям, можно говорить о негативном влиянии данного фактора на реализацию задачи благоприятного отношения к политике переселения соотечественников в регионе.

Ключевые слова: соотечественники, миграция, Алтайский край, информационные ресурсы, информационное поле.
The research approach is based on the consideration of modern migration policy as an incentive stage for the continuous process of the 1990-2000s. In the 1990s, in the context of a conceptual consideration of the resettlement of compatriots in the framework of forced migration, the representation of immigrants as victims of hostilities or discrimination in the country of origin was used as a mechanism for creating a positive image. The concept of "voluntary resettlement of compatriots" requires a different approach in creating the information field. The study is devoted to determining the compliance of the information field of the policy of resettlement of compatriots with the task of creating a favorable attitude towards migrants and a policy of promoting voluntary resettlement in general (using the example of the Altai Territory). It is concluded that the deficient use of cultural and historical discourse brings compatriots as an object of state policy to labor migrants. Considering the fact that information about the conditions for participation in the program, including with regard to benefits for immigrants, is not specific, and seeing user comments on the publications in question, we can talk about the negative impact of this factor on the implementation of the task of a favorable attitude towards resettlement policy of compatriots in the region.

Key words: compatriots, migration, Altai Territory, information resources, information field.

DOI 10.14258/izvasu(2019)2-02

\footnotetext{
^Исследование выполнено при финансовой поддержке РФФИ, проект № 18-311-00287.
} 
Миграционный вектор российской политики взаимодействия с зарубежными соотечественниками актуализировался в 1990-е гг. Концептуально и организационно миграция лиц, оказавшихся за пределами России в результате распада СССР, рассматривалась в рамках вынужденного переселения. Однако отнесение миграционного вопроса в отношении лиц, оказавшихся за пределами России в бывших союзных республиках, к деятельности в сфере поддержки зарубежных соотечественников [1], а также использование механизмов, выработанных в 1990-е гг., в современной переселенческой политике позволяет рассматривать этот период как первый, реакционный этап политики переселения соотечественников. После сокращения иммиграционного потока со второй половины 1990-х гг. миграционная политика все больше принимает ограничительный характер, однако в связи с негативными тенденциями, связанными с сокращением рождаемости, повышением уровня смертности, с миграционным оттоком трудоспособного населения, концептуально соотечественники начинают рассматриваться в качестве ресурса для их преодоления [2, с. 26]. В 2006 г. Указом Президента РФ утверждена Государственная программа содействия добровольному переселению соотечественников на территорию России.

Одной из задач, стоящих перед компетентными органами власти, прежде всего на местах, является информационное обеспечение программы.

В 1990-е гг., в условиях концептуального рассмотрения переселения соотечественников в рамках вынужденной миграции, в качестве механизма формирования положительного образа использовалось представление переселенцев в качестве жертв военных действий или дискриминации в стране исхода, призванное вызвать жалость у местного населения $[3$, c. 24]. Механизм активно используется и в современной ситуации, например, в отношении беженцев с Украины [4, с. 6]. Концепция же «содействия добровольному переселению соотечественников» требует иного подхода при создании информационного поля. Кроме того, исследования 1990-х гг. показывали наличие напряженности во взаимоотношениях местного населения и переселенцев, что определялось, в частности, предоставлением последним льгот в условиях сложной социально-экономической ситуации в регионах и стране в целом. В историографии наибольший интерес представляют исследования образа трудового мигранта в прессе. Это исследование (В.И. Дятлова [5], О.Ф. Варгановой [6, с. 81], Т.Г. Скребцовой [7, с. 115], И.В. Нам [8, с. 166]). Изучение же информационного поля программы переселения проводилось либо в контексте общей миграционной политики [5], либо объектом выступали беженцы с территории Украины, получившие право становиться участниками программы
$[4$, c. 6]. Исследование посвящено определению соответствия информационного поля политике переселения соотечественников как совокупного пространства целенаправленных информационных потоков и дискурсивных практик задаче формирования благоприятного отношения к переселенцам и политике содействия добровольному переселению в целом.

Для анализа выбран Алтайский край как регион Сибирского федерального округа, имеющий наибольший исторический опыт взаимодействия с соотечественниками, проживающими за рубежом. Кроме того, социально-экономическое и демографическое положение края можно охарактеризовать как кризисное: наблюдается устойчивая естественная и миграционная убыль населения, высокий уровень безработицы, низкий уровень средней заработной платы в сравнении с другими сибирскими регионами. Учитывая эти факторы, можно говорить об особой роли информационного обеспечения политики переселения с точки зрения формирования благоприятного отношения.

Источниковой базой являются информационные ресурсы региона, вошедшие в рейтинг компании «Медиалогия» как крупнейшего разработчика системы мониторинга и анализа средств массовой информации по индексу цитируемости. Также были включены региональные официальные порталы компетентных органов государственной власти. Объектами исследования стали публикации, связанные с реализацией региональной программы. При этом были исключены публикации, информационным поводом для которых является политический кризис на Украине, вызвавший массовый приток беженцев, где программа переселения выступает в качестве инструмента их поддержки. В итоговый массив вошли 213 публикаций. Таким образом, источниковую базу составили сайты региональных органов власти (администрации Алтайского края, Главного управления Министерства внутренних дел - 80 публикаций), информационные агентства (ПолитСиб.ру, Амител, Банкфакс - 84), электронные версии региональных газет («Аргументы и факты», «Бийский рабочий», «Комсомольская правда», «Алтайская правда» - 49). Отметим, что из региональных газет наибольший массив публикаций принадлежит «Алтайской правде», учрежденной совместно с правительством Алтайского края (34 публикации). Основным источником публикаций в негосударственных информационных ресурсах выступают информационные агентства.

Методами исследования выбраны контент-анализ и дискурс-анализ. Исследовательские задачи связаны с определением тенденций в формировании информационного поля программы переселения по следующим направлениям: цель реализащии программы и ее актуальность для региона, участники программы как объект ее реализации (образ 
переселениа-соотечественника) и условия участия в программе.

Исследователями выделяются два основных подхода к цели программы - ресурсный (переселение соотечественников, «нужных» для социально-экономического и демографического развития региона) и гуманитарный (как инструмент репатриации) [2]. Для региона наиболее актуально рассмотрение переселения как механизма привлечения квалифицированных специалистов и повышения трудового потенциала в целях социально-экономического развития, что отражено в $31,4 \%$ публикаций. Среди приоритетов отмечается привлечение высококвалифицированных специалистов и молодежи, решение проблемы нехватки кадров в отдельных сферах (педагогических, медицинских кадров, специалистов в области промышленности и сельского хозяйства). 16,9\% публикаций отмечают в качестве цели программы содействие в решении демографических проблем (отток населения, увеличение доли нетрудоспособных граждан и т.д.). Признавая тесную связь социально-экономических и демографических факторов, можно говорить о том, что информационное поле преимущественно представляет программу как механизм привлечения в регион рабочей силы. Стимулирование и организация добровольного переселения, возвращение соотечественников, а также создание условий для адаптации в качестве цели программы отмечается в 6,1\% публикаций. Четких показателей, характеризующих роль программы в социально-экономических и демографических тенденциях в регионе, не представлено. Во многом это связано с тем, что количество переселенцев за годы реализации программы оказалось в несколько раз меньшим предварительных расчетов. Кроме того, в 2017 г. из сибирских регионов миграционный приток населения установлен только в Новосибирской области и Красноярском крае; Алтайский край характеризуется естественной и миграционной убылью. В сравнении с предварительными показателями, а также официальными данными динамики населения в регионе количество переселенцев, действительно, представляется незначительным. Однако, если обратиться к тем же цифрам, то в 2017 г. в Алтайском крае численность переселенцев составила $22 \%$ от показателя миграционной убыли населения, а также 17,3\% от количества международных иммигрантов. При этом край является одним из трех сибирских регионов, в которых количество переселенцев в 2017 г. выросло после 2016 г. при ослаблении потока беженцев из Украины. Таким образом, на данный момент программу следует рассматривать в качестве механизма, тормозящего убыль населения, но не имеющего достаточной интенсивности для ее преодоления.

Несмотря на активное применение понятия «соотечественник» в общественно-политическом дис- курсе, в научном и экспертном сообществе отмечают его нечеткий характер. В анализируемых источниках при его определении на первый план выступают характеристики, имеющие значение, прежде всего, для регионального рынка труда (занятость, востребованная профессия, образование) [9]. Это коррелирует с определяемой целью содействия решению социально-экономических проблем региона, в этом смысле можно говорить о единой концептуальной основе информационного поля. Близость к русской культуре, знание языка, наличие родственной связи по прямой восходящей линии или отношение к народам, исторически проживающим в России, в качестве описания объекта программы определяется лишь в 5,63\% публикаций (в том числе через использование таких дефиниций, как «вновь прибывшие», «возвращающиеся», «уроженцы региона») [10]. 34,2\% публикаций определяют участников по гражданской принадлежности или проживанию за рубежом, однако и употребляемые дефиниции не отвечают на вопрос об объекте программы (граждане СНГ, жители других стран, иностраниы, проживающие в Алтайском крае, и др.). Это обусловливает вопросы о том, кто является объектом данной политики, что отражают комментарии к публикациям ( $\mathrm{Mb}$, конечно, за переселенцев, но раскройте тему, что за люди? [11]). Негативными комментариями сопровождаются публикации о переселенцах с «нерусскими» фамилиями (Чей соотечественник этот Бадалян? Может, я чего не понимаю, но программа была рассчитана все-таки на русских? [12]). При этом в комментариях, выражающих положительное отношение к программе, преобладает идеологический дискурс, восприятие переселенцев как своих, прежде всего, русских (Государство хоть как-то начало помогать русским, брошенным в стра-

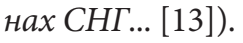

Исключение составляют публикации в формате «human story» [3, c. 26]. Из анализируемых источников 51 публикация $(23,94 \%)$ содержит информацию о конкретных переселенцах. Механизмы представления варьируются от упоминаний в общем контексте основных характеристик переселенцев (состав семьи, условия размещения в регионе) до очерков и интервью. Результаты интервью с переселенцами свидетельствуют о тесной связи социально-экономических и культурных причин переселения, однако одной из основных причин является возвращение в русскоязычную среду. Кроме того, большинство интервью способствует формированию образа семейной и возвратной миграции. Также в качестве положительной практики отметим визуализацию информации (18,3\% публикаций). Несмотря на то, что только в 11 публикациях содержатся фотографии переселенцев, все они трудоспособного возраста, на пяти фотографиях изображены мужчины на рабочих местах, на трех - семьи с детьми. 
Отличительными характеристиками программы является предоставление участникам льгот и компенсаций. Наиболее острыми являются вопросы размещения и трудоустройства, которые чаще всего освещаются в средствах массовой информации. При этом обращает на себя внимание то, что в большинстве случаев информация носит общий характер без конкретизации непосредственных условий. Так, из 49 публикаций, содержащих информацию о возмещении расходов на аренду жилья, только в 15 конкретизируется срок и/или сумма выплаты (с 2 до 6 месяцев при установленной сумме в зависимости от местности проживания). Кроме того, условия программы нацелены на формирование доступа переселенцев к правам местного населения до получения гражданства. В связи с этим значительная часть преференций не является исключительным правом переселенцев, например, возможность получения повышенной стипендии для студентов, частичная компенсация оплаты расходов по договору о получении образования, детские пособия и т.д.).

Таким образом, используемые дискурсивные практики в целом работают на формирование образа переселенцев и программы переселения для привлечения в регион востребованной рабочей силы как ресурса для преодоления социально-экономических проблем.
Это коррелирует с ресурсным подходом к программе и, несомненно, является необходимым фактором при формировании информационного поля. Между тем нечеткость информации об условиях участия в программе, а также о том, кто является объектом политики переселения, в условиях принимаемых законотворческих решений (связанных, в том числе, с отсутствием требования подтверждения знания русского языка) недостаточный акцент на культурную близость участников программы следует обозначить в качестве негативного фактора, способствующего рассмотрению переселения соотечественников с политикой в сфере трудовой миграции. В качестве механизма формирования благоприятного отношения к переселенцам можно отметить использование формата «human story», через который, как правило, отражается потенциал программы как меры стимулирования возвратной миграции. В целом же недостаточное внимание культурному аспекту является предпосылкой к формированию образа программы как механизма замещения при невозможности сделать регион привлекательным для россиян. В этой связи конкретизация информации об условиях участия в программе представляется актуальной не только для переселенцев как объекта информационного обеспечения программы, но и местного населения как принимающего сообщества.

\section{Библиографический список}

1. Основные направления государственной политики Российской Федерации в отношении соотечественников, проживающих за рубежом от 31.08.1994 [Электронный ресурс] // Официальный сайт Константина Затулина. URL: http://zatulin.ru/institute/wbook/201.shtml.

2. Филиппов В.И. Переселение российских соотечественников из постсоветских государств: политико-правовой анализ : дис. ... канд. пед. наук. Бишкек, 2011.

3. Базина Е.С. Тема миграции и мигрантов в российских СМИ: образ «чужого» и проблема информационной объективности // Бизнес. Общество. Власть. 2015. №23.

4. Ефременкова М.Н., Гриценко В.В. Образ мигранта-соотечественника в средствах массовой информации // Социально-психологические проблемы современного общества и человека: пути решения : материалы Международной научно-практической конференции (29-30 октября 2015 г.). Витебск, 2015.

5. Трансграничные миграции и принимающее общество: механизмы и практики взаимной адаптации : монография / науч. ред. В.И. Дятлов. Екатеринбург, 2009.

6. Варганова О.Ф. Образ трудового мигранта в федеральных и региональных СМИ (по результатам контентанализа) // Социологическая наука и социальная практика. 2015. № 3 (11).

7. Скребцова Т. Г. Образ мигранта в современных российских СМИ // Политическая лингвистика. 2007. Вып. 23.
8. Нам И.В. и др. Конструирование образа трудового мигранта в региональных СМИ (на примере Томска) // Сибирские исторические исследования. 2017. №1.

9. Более 300 соотечественников и членов их семей в 2011 году выбрали Алтайский край постоянным местом жительства [Электронный ресурс] // Официальный сайт Алтайского края. URL: https://www.altairegion22.ru/ region_news/e180085.html?sphrase_id/.

10. Представители миграционных служб обсудили в Белокурихе программу переселения соотечественников из-за рубежа в Сибирь и на Дальний Восток [Электронный ресурс] // Официальный сайт Алтайского края. URL: https://www.altairegion22.ru/region_news/predstavitelimigratsionnyh-sluzhb-obsudili-v-belokurihe-programmupereseleniya-sootechestvennikov-izza-rubezha-v-sibir-i-nadalnii-vostok_371279.html?sphrase_id=525478.

11. В Алтайский край переселятся более 2700 соотечественников [Электронный ресурc] URL: http://www.amic. $\mathrm{ru} /$ news $/ 250731 /$.

12. Гражданин Армении переехал жить на Алтай, став участником госпрограммы по переселению соотечественников [Электронный ресурc]. URL: http://www.amic. ru/news $/ 153379 /$.

13. В Алтайский край по государственной программе прибыли соотечественники из Казахстана [Электронный pecypc]. URL: http://www.amic.ru/news/156572/. 